\title{
Inhalt.
}

Erster und zweiter Teil.

Praktische und exegetische Übungen für Anfänger. Einleitung.

1. Recht . prakt. exeget.

2. Privatrecht 117

3. Römisches Privatrecht 118

4. System des römischen Privatrechts 119

Erstes Buch.

Allgemeiner Teil.

5. Privatrechtsverhältnisse

6. Actio und exceptio

7. Dingliche und obligatorische Rechte . . . . . . 19

8. Juristische Personen . . . . . . . . . . . . 21

9. Verwandtschaft . . . . . . . . . . . . . . . 26

10. Servi . . . . . . . . . . . . . . . . . 29

11. Civitas

Zweites Buch.

Recht der Schuldverhältnisse.

12. Obligatio . . . . . . . . . . . . . . . . . 35

13. Verbalkontrakte . . . . . . . . . . . . . 38

14. Kousensualkontrakte . . . . . . . . . . . . 39

15. Realkontrakte . . . . . . . . . . . . . . 42

16. Pacta . . . . . . . . . . . . . . . . . 44

17. Obligationes quasi ex contractu . . . . . . . 47

18. Obligationes ex delicto. . . . . . . . . . . 48

19. Obligationes quasi ex delicto . . . . . . . . . . 52

20. Cession . . . . . . . . . . . . . . . . 54

21. Endigung von Obligationen . . . . . . . . . 56

22. Bürgschaft 
Drittes Buch.

Sachenrecht.

prakt. exeget.

23. Rechtsobjekte. . . . . . . . . . . . . . 62

149

24. Eigentum . . . . . . . . . . . . . . . 64

150

25. Besitz . . . . . . . . . . . . . . . . 70

154

26. Servituten . . . . . . . . . . . . . . . 73

27. Emphyteusis und Superficies . . . . . . . . 76

158

28. Pfandrecht

78

158

Viertes Buch.

Familienrecht.

29. Römisches Eherecht . . . . . . . . . . . 80

30. Dos . . . . . . . . . . . . . . . . . 83

31. Eltern und Kinder . . . . . . . . . . . . 85

32. Patria potestas . . . . . . . . . . . . . . . . 87

33. Tutela . . . . . . . . . . . . . . . . . . 91

34. Cura

Fünftes Buch.

Erbrecht.

35. Grundsätze des Erbrechtes . . . . . . . . . 94

36. Testamenta. . . . . . . . . . . . . . . 97

37. Successio ab intestato. . . . . . . . . . . 101

173

38. Noterbenrecht . . . . . . . . . . . . . 103

174

39. Delatio und acquisitio.

176

40. Vermächtnisse

109

178

\section{Dritter Teil.}

\section{Exegetikum für Vorgerücktere.}

1. Aus dem Leben des Lucius Titres .

Seite

2. Kasuistik der klassischen Jurisprudenz

3. Rechtspraxis des Diocletian und Maximian .

4. NON LIQUET

5. Die Kontroversen der Sabinianer und Proculianer

6. Quinquaginta decisiones Iustiniani

7. Bestrittene Fragmente der römischen Rechtsquellen . . . 221

8. Antinomien im Corpus iuris civilis . . . . . . . . . 233

9. Septem cruces iurisconsultorum . . . . . . . . . . . 243

10. Authenticae Friderici I et Friderici II . . . . . . . . 248 